\title{
THE IMPACT OF THE ENGLISH COMMON LAW ON CARIBBEAN SOCIETY
}

\author{
by \\ HON. MADAM JUSTICE DESIREE P. BERNARD
}

ADVENT OF THE ENGLISH COMMON LAW INTO THE CARIBBEAN:

In the $17^{\text {th }}$ and $18^{\text {th }}$ centuries as Britain expanded her influence throughout the world she took to her colonies all of her institutions - social, financial, religious and legal, inter alia, and established them along identical lines with those in the mother country. With regard to the legal system, the Common Law of England became the Common Law of the particular colony, and the structure of the court system in large measure mirrored that of England with no regard to relevance or suitability to local conditions.

\section{(a) PRESERVATION OF THE COMMON LAW}

Some of the Caribbean islands and the mainland territory of Guyana conquered by the British were no exception. They inherited all of the institutions and the legal system of England. In some of the English-speaking territories of the Caribbean certain aspects of the Common Law of England were expressly preserved as the law of the colony by legislation. In Guyana, for example, the Civil Law of Guyana Act, Cap. 6:01 ${ }^{1}$ passed on $1^{\text {st }}$ January, 1917 was intituled "An Act to codify certain portions of the Roman-Dutch Law of the State and in other matters to substitute the English Common Law and

\footnotetext{
1 Laws of Guyana, Vol. II
} 
Principles of Equity, along with certain English Statutory Provisions for the

Roman-Dutch Law". Section 3(b) provides as follows:

"the common law of Guyana shall be the common law of England as at the date aforesaid including therewith the doctrines of equity as then administered or at any time hereafter administered by the courts of justice in England, and the High Court shall administer the doctrines of equity in the same manner as the High Court of Justice in England administers them at the date aforesaid or at any time hereafter".

This Act was passed to codify certain portions of the Roman-Dutch Law which was applied in Guyana in relation to immovable property. I shall refer to this more specifically later in the presentation.

The island of St. Lucia in like manner expressly provided for the common law of England to apply to certain aspects of the law of the then colony. Article 917A of the Civil Code of St. Lucia, Cap. 242 is to this effect:

"(1) Subject to the provisions of this article, from and after the coming into operation of this article the Law of England for the time being relating to contracts, quasi-contracts and torts shall mutatis mutandis extend to this colony".

This was applied in the case of Mendes v. Philbert ${ }^{2}$ when the Court of Appeal of the West Indies Associated States held that the effect of $\underline{\text { Art. }}$ 917(A) of the Civil Code was to make the English common law doctrine of scienter part of the law of St. Lucia, and since this point was not raised at the trial where a respondent sued for damages for personal injuries arising from an attack from dogs, the magistrate's order awarding the respondent damages was erroneous and would be set aside.

\footnotetext{
${ }^{2}$ (1971) 16 WIR, 255
} 


\section{(b) STRUCTURE OF THE COURT SYSTEM:}

The English court structure in most instances was transported in toto into the Caribbean territories without reference to relevance, cultural patterns or size of the particular island or state. Provision was made for magistrates' courts, district courts and high courts. All appeals from the high courts or supreme courts of the Caribbean territories went to the Privy Council in England, and in most cases this is still so. In the middle of the 20th century there was established an intermediary court of appeal with a varied nomenclature - first the West Indian Court of Appeal, then with an attempt at federation, the Federal Supreme Court, and lastly the British Caribbean Court of Appeal. With the advent of independence most of the states established their own courts of appeal and retained appeals to the Privy Council. Guyana abolished appeals to the Privy Council in 1970.

There have been, still and will continue to be arguments for and against the retention of the Privy Council as the final court of appeal of the Caribbean region, and I shall return to this topic later in the presentation.

In some instances certain states of the Caribbean have established special courts to meet special needs in the particular society. One example of this was the establishment of the Gun Court in Jamaica in the early 1970's to deal with the alarming rise in crimes involving the use of firearms. Family Courts have also been established in some Caribbean territories to adjudicate on all matters pertaining to the family. Of course, there have been for several years in some territories, for instance, in Guyana, Juvenile Courts which were established to handle all matters affecting juveniles, and were presided over 
by a magistrate who held the hearings of criminal offences committed by juveniles in camera. Probation officers were utilised to carry out investigations of the juvenile's family background with a view to determining punishment which invariably involved committal to a correctional and rehabilitation centre.

In Guyana there was also established a Land Court with jurisdiction to adjudicate on petitions for declarations of title to land having regard to the Roman-Dutch system of conveyancing.

In the colonial era nearly if not all of the courts of the Caribbean colonies were presided over by English magistrates and judges mainly with little or no knowledge of local customs and cultural traditions. They applied the English rules and laws rigidly and uncompromisingly sometimes with ridiculous results, e.g. there was provision in the laws of some states for deeming someone found wandering "a rogue and vagabond", and imposing a term of imprisonment when all that he may have been guilty of was not having a home or a family.

The Caribbean courts during this period in our history also followed the rules of procedure of the English courts. The English Rules of the Supreme Court formed the base upon which the rules of court of the colonies were founded. In most instances these rules were taken verbatim from the English rules. However, in some instances procedural rules were formulated to meet local conditions, e.g. in Guyana there are rules regulating the procedure for entering oppositions to the passing of conveyances for land which is based on the Roman-Dutch system, and is peculiar to Guyana. Also peculiar to 
Guyana and some other Caribbean territories were the rules permitting barristers-at-law to act as solicitors prior to the fusion of the profession.

EXAMPLES OF JUDICIAL ADAPTATION OF ENGLISH COMMON LAW TO LOCAL SITUATIONS

(a) FAMILY LAW

As in other areas of the law the English matrimonial rules were applied Inflexibly with sometimes catastrophic results. The case of Henry v. Henry ${ }^{3}$ which is a decision of the Supreme Court of Trinidad \& Tobago Appellate Jurisdiction is an excellent example of the impact of the English common law on society in the Caribbean and the effects it can have on the lives of its people. In that case a wife lawfully married under the provisions of the Muslim Marriage and Divorce Registration Ordinance, Cap. 29, No. 4 brought a complaint against her husband under the Separation and Maintenance Ordinance for maintenance on the grounds of his wilful neglect to maintain her. The magistrate found the complaint proved and made an order. The husband appealed. At the hearing of the appeal further evidence was received from an expert witness in Islamic law and custom, which established that Muslim marriages are potentially polygamous. It was held,

(i) that the only kind of marriage that entitled the parties thereto to the remedies, adjudication and relief of the matrimonial law of England upon which the Trinidad and Tobago general law relating to marriage is based, is a marriage that is monogamous in the Christian sense of the term, and

${ }^{3}$ (1959) 1 WIR, 149 
(ii) that a Muslim marriage not being monogamous in the Christian sense of the term, the magistrate had no jurisdiction to make an order for maintenance in this case.

A learned Chief Justice in the course of the judgment made this comment:

"It is a well-established principle of law that the only kind of marriage that entitled the parties thereto to the remedies, adjudication or relief of the matrimonial law of England (which is the basis of our general law relating to marriage) is a marriage that is monogamous in the Christian sense of the term".

He went on to refer to the oft-quoted dicta of Lord Penzance in the case of Hyde v. Hyde ${ }^{4}$ to the effect that marriage as understood in Christendom was defined as the voluntary union for life of one man and one woman to the exclusion of all others. This will require reconsideration in changing times.

The decision turned mainly on the wording of the Muslim Marriage and Divorce Registration Ordinance which provided for the registration of Muslim marriages and divorces, but did not stipulate (unlike the Hindu Marriage Ordinance) that a marriage solemnised between persons professing the Muslim faith shall be valid as if it had been solemnised in conformity with the provisions

of the Marriage Ordinance which related to marriages between persons of the Christian religion.

It must have seemed incredible to nationals of a country whose marriage had been registered in accordance with the law to discover that that marriage was regarded as polygamous and not recognised because it did not

${ }^{4}$ (1866) L.R. 1 P \& D, 133 
conform with the Christian and English concept of marriage and was "repugnant to local matrimonial law" (a quotation of Counsel for the appellant).

A court of similar jurisdiction in Trinidad and Tobago in the later case of Mohamed v. Mohamed ${ }^{5}$ did not depart from this position where on an application by a wife of a marriage registered under the same Muslim Marriage and Divorce Registration Ordinance for an order against her husband for maintenance for the children of the said marriage, it was held that even though, as for herself, the wife is not entitled to the remedies, adjudication and relief afforded by the matrimonial law applicable to monogamous unions in the Christian sense of the term, she nevertheless enjoyed a legally married status by the laws of Trinidad and Tobago, and the legitimation of the children of her marriage by statute had the effect of clothing her with the status of a mother within the meaning of the Infants Ordinance.

The anomaly thus created had the effect of denying a wife married under the Muslim faith the right to sue her husband for maintenance for herself not

being regarded as a married woman within the meaning of such a term according to the English concept of marriage, but permitting her to sue her husband for maintenance for their children who were regarded as legitimate under the same Muslim Marriage and Divorce Registration Ordinance.

This was the impact of the English common law on Caribbean society, and a clear example of discrimination against a section of people born within our region and entitled to the protection of our laws. Of course, we must be mindful of the fact that these cases were decided during colonial times and in

5 (1960) 3 WIR, 202 
the pre-Independence era of the Caribbean, and may have been decided differently now with legislation which would have sought to correct the anomaly.

In most of the Caribbean territories English matrimonial law was applied, and the grounds for the dissolution of a marriage were the same as those in England with the exception of Guyana where there exists the RomanDutch concept of malicious desertion which is desertion proceeding "ex malitia", i.e., from design or pre-meditated determination. The ratio decidendi in the case of Siebs $\mathbf{v}$. Siebs ${ }^{6}$ indicates the influence of the concepts of English law on a Roman-Dutch concept when the Court of Appeal held that there was no difference in the state of mind required to found malicious desertion and that of the English doctrine of constructive desertion. A Court of Appeal Judge in the course of his judgment made this comment:

"For my part, I can find no difference between the state of mind required to found malicious desertion, and that which must exist in the spouse whose conduct leads the other spouse to depart from the matrimonial home. The object is the same; the mode of achieving that object is different".

Guyana still remains the only country in the region which has retained this peculiar concept of malicious desertion, and is at present no more than a nomenclature for the concept of desertion. In the very near future it may fade into history when the sole ground for dissolution of a marriage will be its irretrievable breakdown based on a separation for a specified period.

(b) LAW OF MOVABLE AND IMMOVABLE PROPERTY

As mentioned earlier the Civil Law of Guyana Act,

${ }^{6}$ (1969) 14 WIR, 72 
Cap. 6:01 ${ }^{7}$ sought to codify certain portions of the Roman-Dutch Law in relation to immovable property. Section 3 (c) expressly provided that the English common law of real property shall not apply to immovable property in Guyana and Section $\mathbf{3}(\mathbf{d})$ is to this effect:

"There shall be as heretofore one common law for both immovable and movable property, and all questions relating to immovable property within Guyana and to movable property subject to the law of Guyana shall be adjudged, determined, construed and enforced, as far as possible, according to the principles of the common law of England applicable to personal property: with certain provisos".

The effect of this was that all English principles concerning personalty were now to be applied to immovable and movable property alike in Guyana.

The concept of the "chattel house" unknown to English law is a peculiar phenomenon of Caribbean society and most territories have given it statutory recognition. Under Section 2 of the Summary Ejectment Ordinance, Cap. 27, No. 17 of Trinidad and Tobago "premises" meant "lands, houses or other corporeal hereditaments, and includes chattel or movable houses". In a case in 1963 the learned judge stated in his judgment that the manner of its statutory insertion indicated that the chattel house had become a part of the common law of Trinidad and Tobago, [and] it seemed appropriate, therefore, to apply the principles developed by the courts in England to this locally important, if novel, off-shoot in the law of real property. He held in that case, inter alia, that the house (the subject matter of the dispute) was a type of fixture which attracted a relaxation of the general rule as to annexation of

${ }^{7}$ Laws of Guyana, Vol. II 
chattels to the soil and was consequently removable as a tenant's fixture at the end of or during the term of the tenancy.

\section{(c) DOCTRINE OF UNJUST ENRICHMENT}

The doctrine of unjust enrichment came up for consideration before the Court of Appeal of Guyana in 1970 in the case of Peter Persaud and others v. PIn. Versailles \& Schoon Ord. Ltd., ${ }^{\mathbf{8}}$ and as happened in England there were divergent views. One Justice of Appeal expressed grave doubt as to whether the law of unjust enrichment is part of the law of Guyana, while another felt that there was no impediment to the application of the doctrine as the jurisdiction of the High Court of Guyana is not fettered from itself developing and expanding the common law with the aid of the principles of equity in fitting cases.

This case concerned the deductions from their wages of amounts due by employees, the appellants, for food and drink consumed by them as members of a staff club, and payment for which they had authorised their employers, the respondents, to deduct from their wages. The club was later closed, but the employers continued to make the deductions for outstanding amounts due by the employees to creditors of the club. The appellants launched proceedings to recover the amounts thereby deducted. One Judge in the course of his judgment at page 130 had this to say:

"Underlying the law of restitution is the conception that no one should unjustly enrich himself at the

${ }^{8}$ (1970) 17 WIR, 107 
expense of his neighbour. As I see it, I must march with those in the vanguard of progress and try to develop the law by means of the application of equitable remedies in the dualism of common law and equity which is sanctioned by and built into our legal system - see S. 3 (B) of the Civil Law of Guyana Ord. Cap. 2".

One can never over-emphasise the urgency for the courts of our region to develop a jurisprudence of our own, by modifying or expanding the common law to meet local situations and the justice of a particular case.

\section{(d) CRIMINAL LAW}

\section{(i) STARE DECISIS}

As in the civil jurisdiction of our courts the influence of the English law and precedent has been no less pervasive in the criminal law. We inherited all of the English criminal offences, defences, and the jury system. We have been throughout the years guided by their decisions, e.g. Section 3 of the Criminal Law (Offences) Act, Cap. 8:01 of Guyana ${ }^{9}$ first passed in 1894 provides as follows:

"Subject to the provisions of this Act and of any other statute for the time being in force all the rules and principles of the common law relating to indictable offences and other criminal matters shall, as far as they are applicable to the circumstances of Guyana, be in force therein".

Section 16 of the Criminal Law (Procedure) Act, Cap. 10:02 ${ }^{10}$ also first passed in 1894 in like manner provided that the practice and procedure in

\footnotetext{
9 Laws of Guyana, Vol. II

10 Laws of Guyana, Vol. II
} 
criminal causes and matters shall be the same as that in the High Court of Justice and the courts of assize and of gaol delivery in England. However, within recent times in England most criminal offences have become statutory offences differing in some respects from ours and sometimes not relevant to our behavioural patterns. There may be occasions when we find ourselves unable to follow judgments of the English courts which we feel were wrongly decided. This view was expressed by a Judge of the Court of Appeal of Guyana in the case of The State v. Sookraj Evans ${ }^{11}$ where he held that the Guyana Court of Appeal should act on the principle that although for obvious reasons it will be predisposed to accept and normally will accept a judgment of the House of Lords on a point of English common law as correct and as our law, it has jurisdictional freedom and a constitutional judicial duty to hold differently, if the Court is convinced fully on just grounds that the principle or rule laid down in it or the declaration of what is not the common law, is misconceived and wrong.

Opinions have been expressed that courts of the Commonwealth must feel free to develop and interpret common law principles as they seem fit having regard to local conditions and whether they consider particular decisions of the English courts wrongly decided, without being obliged to follow them because of statutory compulsion or to preserve judicial uniformity.

\section{(ii) ADMINISTRATION OF OATHS TO WITNESSES}

11 (1975) 23 WIR, 189 
Oaths taken by witnesses have throughout the history of the English common law followed prescribed forms, and have been administered in conformity with Christian principles. However, there have been cases decided in the English courts where witnesses have been permitted to swear to oaths in accordance with what is binding on their conscience.

In the Caribbean our courts have followed the format of and manner in which oaths are administered in England and which are based on the Christian religion. With the advent of the Rastafarian religion in the Caribbean the Jamaican courts were called upon to determine whether the refusal of a trial judge to permit an accused to be sworn in a form which he considered binding on his conscience and which was not in the prescribed form, was

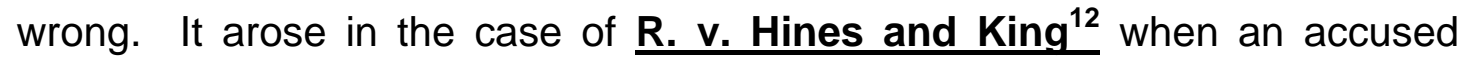
declined to be sworn in the form prescribed by $\underline{\mathbf{S} .3}$ of the Oaths Law, Cap.

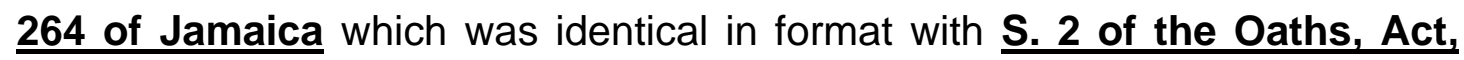
1909 of England, and began "I swear by Almighty God ........." His reason for refusing to be so sworn was that he professed the Rastafarian faith and would only consider himself bound by an oath in the form commencing "I swear by Almighty God, King Rastafari....." as he and other members of that faith regarded and worshipped the Emperor of Ethiopia as "the true and living God that sits on the throne of David". The trial judge refused to permit Hines to be sworn in a form other than that prescribed by $\underline{\mathbf{S} .3}$ of the Oaths Law, Cap. 264 stating that as far as he knew an oath taken in the form in which Hines wished to take it was not lawful. Hines rested his case, and was convicted. On appeal, it was held that the trial judge erred in refusing to 
permit Hines to be sworn in a form which Hines declared to be binding on his conscience and in so doing deprived the accused of his right to give sworn testimony in his defence and his convictions therefore could not stand.

A Justice of Appeal in the course of his judgment made reference to $\underline{\mathbf{S . 2 1}}$ (5) of the Constitution of Jamaica which enacts that:

"No person shall be compelled to take any oath which is contrary to his religion or belief or to take any oath in a manner which is contrary to his religion or belief".

However, S. 3 of the Oaths Law Cap. 264 of Jamaica was based on and was identical in content to $\underline{\text { S. } 2 \text { of the Oaths Act, 1909. The learned }}$ Judge remarked that as far as those statutory enactments went the position in England and Jamaica appeared to be the same, but posed the question whether the prescribed statutory form and manner for the administration and taking of an oath was compulsory or permissive. He observed that having regard to the multitude of different religious beliefs which exist in the world it is to be expected that an oath under the common law would take some of very many forms. He traced the history of the present Jamaican statutory provision based throughout on English legislation, and concluded that there is nothing in the enactments which have been traced - English or Jamaican which would have the effect of rendering invalid an oath administered or taken in a form and manner permissible under the common law. He summed up his conclusions in relation to the appellant Hines in this way:

“..... However misguided one may think Hines to be in his professed belief as a member of the Rastafarian sect that the Emperor of Ethiopia is a Divine Being, the fact remains that such is his professed belief and indeed the professed belief of the sect to which he belongs. The form in which Hines wished to take the oath was consistent 
with that professed belief and declared by him to be binding on his conscience......."

This case exemplifies the impact of the English common law on local custom and religion not always negatively, but sometimes positively ensuring the development of our mores and the ethos of our own jurisprudence.

\section{ABOLITION OF APPEALS TO THE PRIVY COUNCIL AND ESTABLISHMENT OF A REGIONAL COURT OF APPEAL}

It is apposite at this point to consider the desirability of developing a jurisprudence peculiar to our needs, culture, traditions and regional objectives. I think it is imperative that we pause and reflect on how appropriate certain aspects of the English common law and legal systems are to our region, and not follow the tried and beaten path of English precedent. Inextricably tied to this laudable goal is the compunction to establish our own final court of appeal. We have taken our own political, economic and social destinies into our own hands with the assumption of independent status in all but one or two of the Caribbean islands and the establishment of the Commonwealth Caribbean Community. Several years before these events we became a force to be reckoned with in the field of cricket being invincible against our former colonial masters, yet we cling tenaciously to a court thousands of miles away established in colonial times to consider and determine appeals from its colonies.

Several of England's former colonies have severed the umbilical cord and established final courts of their own, but we in the Caribbean along with one or two other Commonwealth territories seem reluctant to leave the nest 
and fly with our own wings. Happily, in April 2005 the Caribbean Court of Justice was inaugurated with two jurisdictions - original and appellate. All of the member states of the English-speaking Caribbean together with Suriname and Haiti have acceded to the original jurisdiction having empowered the Court to apply and interpret the provisions of the economic treaty - the Revised Treaty of Chaguaramas. However, only three states have acceded to the appellate jurisdiction - Barbados, Guyana and Belize. There have been recent press reports that Dominica will be delinking from the Privy Council, and will be the new member of the CCJ.

This Court is still in its infancy being just eight years old, but the appointments procedure for the recruitment of judges has received commendation internationally. The appointments are made by an independent Regional Judicial and Legal Services Commission comprising representatives of the Regional Bar Associations, the Regional Public Service Commissions, the regional Universities, and civil society. The governments of the Region have no control over the appointments, and judges sit on the Court in their personal capacities, and not as representatives of their country of birth. They are appointed if they satisfy the required criteria, and are drawn from common law jurisdictions and civil law jurisdictions if proficient in international law. Only the appointment of the President of the Court requires the formal approval of the States upon a recommendation of the Commission.

I think the time has come for the peoples of the Caribbean Region to take control of the administration of justice as has been the case in relation to other aspects of Regional responsibilities. Who better can judge whether a chattel house on blocks in the gap in St. Lawrence, Barbados, belongs to the 
tenant or the owner of the land or whether a member of the Rastafarian religion in Kingston, Jamaica or Kingstown, St. Vincent, ought to swear by Jah or the financial implications of holding a box hand in Guyana or sou-sou as it is called in Trinidad and Tobago? Only nationals of the Caribbean know what this means.

This fact was highlighted by the Privy Council in the case of John and Others v. Director of Public Prosecutions for Dominica ${ }^{13}$ when it held, inter alia, that questions of the evaluation of evidence are essentially matters for a local appellate court and are not matters upon which, generally speaking, the Judicial Committee of the Privy Council would presume to differ from that court, whatever view their Lordships might have been disposed to take had the appeal in question initially come before them.

We shall have failed in our duty to ourselves and to the future generations of Caribbean jurists if we do not establish our own judicial institutions and develop our own jurisprudence thereby bequeathing to those yet unborn a heritage of which they can be justly proud.

\section{CONCLUSION}

Whatever the shortcomings and deficiencies of the common law it was an invaluable legacy inherited by Britain's former colonies, and has been a unifying force among countries that share the same legal system. Its influence may be slowly waning even in the motherland that gave it birth as time and again it has yielded to statute which threatens to obliterate it

13 (1985) 32 WIR, 230 
completely. English law is fast becoming codified as the legislature seeks the medium of a statute to correct defects which surface in the common law and to provide remedies where none existed before.

The influence of Britain on her former colonies is strong, and despite their independent status many countries of the Commonwealth very often follow verbatim the wording of English statutes in drafting their own. In spite of and maybe because of the varied mosaic of cultures, traditions and customs of the countries which share the same history of English colonialism, the common law and the body of precedent built up around it has been enriched in its development, and made strong, and dynamic. May it always remain so even in a world which is changing rapidly and moving inexorably forward.

Delivered at the Institute of Advanced Legal Studies Charles Clore House Russell Square London WC1, England $2^{\text {nd }}$ December, 2013 